\title{
Job Satisfaction of Canadian University Librarians: A National Survey
}

\section{Gloria J. Leckie and Jim Brett}

This study investigates the job satisfaction of Canadian university librarians, using a replication of a 1993 American study to facilitate international comparisons. ${ }^{1}$ It explores the relationships between faculty/ academic status, administration, and the participation of librarians in library planning and decision-making, university affairs, and professional activities. A survey was sent to all university librarians in Canada, resulting in 738 usable responses. Data analysis concentrated on comparisons between faculty- and non-faculty-status librarians, and administrative and nonadministrative librarians. Although faculty-/academicstatus librarians were significantly more satisfied with their involvement in university affairs and promotion and tenure processes, they were not more satisfied with other dimensions of their work, such as workload and salary. Administrative librarians, on the other hand, were significantly more satisfied with most of the major aspects of work being measured, and perceived themselves to be much more involved in library planning and university affairs than did nonadministrative librarians.

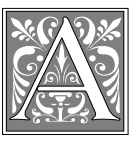

cademic librarians work in a unique setting. The challenge of being in a dynamic environment of research and learning is often viewed as an intangible benefit of their jobs. Yet, despite the excitement of participating in the constant changes in higher education over time, the daily reality of the university is one of ponderous stability: a very large proportion of the staff stay within the institution for their entire careers. Although faculty are the most likely to follow this pattern, the same is also true for many academic librarians, giving rise to concerns over the ability of individuals to stay motivated, involved, and happy in their positions, particularly if there are no opportunities for advancement. Thus, the question of what makes academic librarians satisfied or dissatisfied with their work over the long run has been of interest for decades and has generated a number of studies.

In much of the research about job satisfaction among academic librarians, two kinds of relationships have been investigated. The first of these is the relationship between the characteristics of academic librarians' work and their job satisfaction. Studies taking this approach 
have looked at specific components of professional work, including workload, autonomy, creativity, challenge, specialization, decision-making, control, salary, benefits, and various other characteristics. $^{2}$

Another major avenue of exploration evident in the literature is the relationship between the relative institutional status of academic librarians (vis-à-vis other groups of employees) and their overall job satisfaction. Studies pursuing this line of investigation reflect an issue particular to academic librarians, that being the requirements of the faculty- or academic-status model. Aspects examined include librarians' involvement in, and satisfaction with, research and publication, teaching, tenure, collegiality, peer review, and participation in decision-making within the library and the wider university. ${ }^{3}$ Questions often considered are whether academic librarians who have faculty status or equivalent are more or less satisfied with their work than academic librarians who do not have faculty status within the university, and whether librarians who are required to do research and publish are more or less satisfied than those who do not.

Unfortunately, both kinds of studies often produce conflicting or confusing results, arising because of three major problems. First, much of the research uses different variables and different instruments to assess satisfaction. Steven Chwe, for instance, looked at areas of work as a potential cause for differences in satisfaction, and noted that although catalogers and reference librarians had no significant differences in overall satisfaction, there were aspects of their work that reference librarians found to be more satisfying than catalogers. ${ }^{4}$ Susanne Wahba and Ilene Rockman were interested in the impact of gender on satisfaction, and suggested that it did seem to play a part in overall job satisfaction, although D'Elia refuted this finding. ${ }^{5-7}$ Patricia Kreitz and Annegret Ogden examined levels of responsibility as an important aspect of academic librarians' satisfaction, demonstrating that the higher levels of responsibility and control over their work experienced by librarians could account for their higher levels of job satisfaction when compared to library assistants. ${ }^{8}$ Bonnie Horenstein investigated the relationship between faculty status, participation, and satisfaction, and concluded that participation was a determining factor in job satisfaction. ${ }^{9}$ Marjorie Benedict explored satisfaction with faculty status, and found that librarians with professorial ranks and titles were the most satisfied..$^{10}$ Recently, Tina Hovekamp has looked at the impact of union membership on academic librarians' job satisfaction, noting that it was associated with lower levels of satisfaction. ${ }^{11}$ Although all these studies have useful and interesting findings, it is often hard to make comparisons and thus to arrive at a greater understanding.

Beyond the problems inherent in the choice of variables and instruments, a second issue is that, with a broad range of types of postsecondary institutions in the United States and Canada, the work of academic librarians varies considerably with institution type, making it difficult to conduct comprehensive surveys that are meaningful. And, third, even if the group of academic librarians under study is limited to a specific type of institution (such as librarians in researchintensive universities or liberal arts colleges), very few studies are ever replicated using another population of academic librarians for direct comparison.

This study addresses the first and third problems with a Canadian replication of Bonnie Horenstein's 1993 study of job satisfaction among American academic librarians. ${ }^{12}$ Her study examined both job satisfaction in general and with respect to faculty status, as well as the librarians' participation in library decision-making, university affairs, and professional activities. The broad range of general factors 
as well as the specific aspects of the faculty-status model covered in the survey were appealing, because we were also interested in these issues in the Canadian context. Accordingly, Horenstein's survey was amended slightly (discussed below) and sent out to the entire population $(1,558)$ of librarians working in Canadian universities.

\section{Purpose}

The overall purpose of the study was to follow up on earlier research into the nature of faculty status for Canadian university librarians. ${ }^{13}$ In that study, the authors reviewed the evolution of the faculty-status model as applied to Canadian university librarians, noting that only a small number of sites actually have full faculty status (with the same ranks, titles, and evaluative criteria used by the faculty). In Canada, the general practice is to grant university librarians a modified form of faculty status commonly referred to as academic status, a term that will be used consistently throughout this article. ${ }^{14}$ The authors then analyzed the collective agreements at institutions where librarians had academic status and determined that the components of academic status in the agreements varied quite widely across institutions. With so little common understanding of the terms and meaning of academic status, the authors speculated that there seemed to be no unified vision of academic librarianship in Canada. They further wondered if the lack of agreement about academic status would be reflected if academic librarians were asked about their job satisfaction. Accordingly, the authors set out to conduct a national survey of the job satisfaction of Canadian university librarians, a feat that had never before been attempted. Within that broad framework, the study had two goals.

The first goal was to explore a series of questions relating to the job satisfaction of Canadian university librarians. Would academic status be related to job satisfaction in the Canadian context? If so, what were the elements of this relationship? If not, what other factors might contribute to satisfaction or dissatisfaction?

The second goal was to draw comparisons with Horenstein's American study. Would Horenstein's finding that job satisfaction was very closely related to faculty/academic status be confirmed? Would librarians with academic status perceive themselves to be more involved in library planning and decision-making, as Horenstein had found? If not, what could account for the differences between Canadian and American academic librarians?

\section{Methodology}

To answer the questions above, Horenstein's original survey was amended and sent out individually to all university librarians across Canada. Because the population of university librarians in Canada is much smaller than in the United States, the authors decided against sampling. When a possible response rate in the area of 20 percent was taken into account, achieving a data set comparable to Horenstein's $(n=683)$ required a survey of the entire group. A master mailing list was compiled from a number of existing Canadian library directories and through personal contacts. The final list consisted of 1,558 librarians, including those in both managerial and nonmanagerial positions (Horenstein did not include managers). A small amount of funding obtained for the study enabled the authors to mail to individuals rather than to directors for distribution, thus ensuring a better and more representative response.

Horenstein's restriction to institutions with enrollments larger than 2,000 students was not replicated because almost all Canadian universities are government supported, and few have an enrollment that small. Thus, in an effort to be comprehensive nationally, the authors did 
include smaller institutions. However, these institutions account for less than 5 percent of the librarians surveyed, so it is doubtful that their inclusion would significantly bias the results in terms of comparability with the American study.

To facilitate later comparisons, the authors made as few revisions as possible to the survey instrument. They did alter

\section{Sixty-three percent of librarians indicated that they had academic status, whereas 36 percent had professional or other status.}

the order of the background questions (having to do with education, experience, salary, department, etc.) from the original. Also, because the authors intended to conduct a national survey and wanted to include all academic librarians (including managerial librarians), they added a category of administration to the question about primary department or service area. ${ }^{15}$ Furthermore, they amended the questions that asked about specific components of the faculty-status model (such as elibigility for tenure, sabbatical, etc.) to reflect Canadian conditions. The authors also added some questions not in Horenstein's original survey that had to do with collective representation and committees, evaluation of colleagues, relationship with support staff, and performance review and promotion processes. The bulk of the questions then asked librarians to rate thirty-two variables covering major aspects of their work, and were identical or very similar to the comparable questions on Horenstein's survey.

The numerous idiosyncracies of translating the survey into French were handled by Marc Richard, a librarian at McGill University. Both the English and French versions were pretested in early fall 1995, and a few adjustments were made based on the pretest. The final surveys were mailed out in October 1995.

\section{Response and Data Analysis}

Seven hundred and forty surveys were returned, realizing a response rate of 47.4 percent, far exceeding the authors' expectations. Like Horenstein, the authors were surprised at the high rate of return, and can only speculate that the topic is of great interest to Canadian university librarians, many of whom previously had not been asked about their job satisfaction. One hundred and sixty-two people also took the time to provide comments, some of which were rather lengthy, and numerous others requested a copy of the findings, thus further suggesting widespread interest in the topic. Out of the 740 responses, only two surveys proved to be unusable. Thus, 738 surveys were coded and entered into an SPSS for Windows data matrix for analysis.

Horenstein identified three groups of librarians for comparison, using combinations of faculty status and rank variables. Because of the nature of faculty status in Canada, the authors could use only two groupings, based on responses to question 8: those with academic status ( $\mathrm{n}=463)$, and those with nonacademic status $(n=269)$. As data entry was taking place, the authors noted that librarians who had indicated administration as their primary department or service area $(n=279)$ appeared to have slightly higher levels of job satisfaction, so it was decided to conduct some comparative analyses of that group as well.

\section{Respondents}

General characteristics of the respondents are presented in table 1. A large percentage of the respondents $(62 \%)$ in the study had more than fifteen years' experience as librarians, as Horenstein also found. ${ }^{16}$ Ninety-four percent of respondents held a master's degree in library and information science or equivalent, and about one-quarter had a second master's degree. Administration and reference were the two most common service areas indicated, although librarians 


\begin{tabular}{|c|c|c|c|}
\hline \multicolumn{4}{|c|}{$\begin{array}{c}\text { TABLE } 1 \\
\text { Characteristics of Respondents }\end{array}$} \\
\hline Characteristic & $\%$ of sample & Characteristic & $\%$ of sample \\
\hline Experience & & $\underline{\text { Salary }}$ & \\
\hline $0-3$ years & 5.3 & $<\$ 30,000$ & 2.2 \\
\hline 4-9 years & 16.7 & $\$ 30-40,000$ & 12.2 \\
\hline $10-15$ years & 16.0 & $\$ 40-50,000$ & 20.3 \\
\hline \multirow[t]{2}{*}{$>15$ years } & 62.1 & $\$ 50-60,000$ & 29.5 \\
\hline & & $>\$ 60,000$ & 35.7 \\
\hline \multicolumn{4}{|l|}{ Education } \\
\hline MLS & 94.4 & $\underline{\text { Status }}$ & \\
\hline Extra master's & 27.4 & $\overline{\text { Academic/faculty }}$ & 63.3 \\
\hline Ph.D. & 4.6 & Professional/other & 36.8 \\
\hline Gender & & Eligible for Tenure/ & \\
\hline$\overline{\text { Female }}$ & 67.9 & Continuing Appointment & \\
\hline \multirow[t]{2}{*}{ Male } & 32.1 & Yes & 86.4 \\
\hline & & No & 13.3 \\
\hline \multicolumn{4}{|l|}{ Primary Department } \\
\hline Acquisitions & 0.8 & Eligible for Sabbatical & \\
\hline Administration & 37.8 & Yes & 77.9 \\
\hline Cataloging & 10.3 & No & 22.1 \\
\hline Circulation & 0.1 & & \\
\hline Collections & 8.1 & $\underline{\text { Publication Requirements }}$ & \\
\hline ILL & 0.9 & None & 31.7 \\
\hline Reference & 33.2 & Encouraged only & 40.4 \\
\hline Serials & 0.9 & Some required & 23.1 \\
\hline Systems & 3.0 & Substantial record required & 4.8 \\
\hline \multirow[t]{2}{*}{ Other } & 4.7 & & \\
\hline & & \multicolumn{2}{|c|}{ Eligible for Seats on University } \\
\hline Management Style & & Governance Structures & \\
\hline Autocratic & 25.0 & Yes & 89.4 \\
\hline Collegial & 41.3 & No & 10.6 \\
\hline Team & 22.2 & & \\
\hline Other & 11.5 & & \\
\hline
\end{tabular}

from every service area were represented. Salaries tended to be on the high side, with 65 percent of librarians earning more than $\$ 50,000$ per year.

Sixty-three percent of librarians indicated that they had academic status, whereas 36 percent had professional or other status. A very large proportion of respondents $(87 \%)$ indicated that they were eligible for either tenure or continuing appointment, a much higher figure than the 58 percent eligible for tenure in the American study. The higher figure is undoubtedly because the question on eligibilty for tenure was reworded as "eligibility for tenure or continuing appointment." In Canada, the phrase "continuing appointment" is commonly used to describe a tenurelike process for librarians, but it can also apply to non-facultystatus librarians, thus increasing affirmative responses to this question. The majority of librarians have relatively little pressure to do research and publish: 72 percent indicated that research and publication were not required, even though 
they might be encouraged. This is slightly higher than in Horenstein's sample, where 65 percent of respondents indicated that little or no research and publication were required. Seventy-eight percent of librarians in the study were eligible for research leave, and 89 percent indicated that they were eligible to hold

In other words, levels of satisfaction with workload were below satisfactory on the scale.

seats on university governance bodies, again suggesting that these privileges are extended to non-faculty-status librarians at some insitutions.

In terms of representation for job-related negotiation, a large majority $(70 \%)$ of librarians indicated that they were represented by their faculty association or union. The next most common form of representation (13\%) was a professional/ managerial association or union.

Finally, responses to the question on management style in the library suggest that an autocratic style of academic library management appears to be waning. Sixty-three percent of librarians indicated that the management style in their library was based on either a collegial or team model. Another 11 percent indicated "other," with many respondents making comments that their library was in transition to a more collegial or team approach.

\section{Elements of Satisfaction}

As Horenstein notes, the aspects of job satisfaction on the questionnaire were derived from numerous studies, and include both intrinsic and extrinsic measures. ${ }^{17}$ Intrinsic items are those that reflect the nature of the work, such as assigned duties, using your own judgment, and opportunities for challenge. Extrinsic items are those that are external to the work, such as salary, benefits, promotion opportunities, and so on.
The various aspects of job satisfaction were measured using a five-point scale, with five being highly satisfactory, three being satisfactory, and one being highly unsatisfactory. In addition to all the particular aspects of their work, a final item asked respondents to scale their overall job satisfaction. Also, a second measure of overall satisfaction was calculated by summing the responses to all the satisfaction variables for those individuals who had completed all those items. Horenstein found that this composite measure provided a slightly more reliable measure of overall satisfaction than the final question alone. ${ }^{18}$

The response to the final question on "overall satisfaction with your job" resulted in a mean response of 3.59 ( $\mathrm{n}=$ 724). Thus, as in Horenstein's study, librarians responding to the Canadian survey reported above satisfactory levels of overall job satisfaction. Higher levels were also confirmed using the composite satisfaction variable, with a mean response of 78.57 ( $n=591 / \mathrm{sd}=17.22$ ). Within the composite satisfaction variable, a mean value of seventy-two indicates "satisfactory" and a value of one hundred twenty indicates "highly satisfactory."

The specific elements of satisfaction for all the respondents are shown in table 2 , ranked in order of most to least satisfactory items. In Horenstein's original study, the item providing the most satisfaction for librarians was their relationship with library users. At the time, the authors found this somewhat puzzling, considering that all types of librarians were included in the study, some of whom (like technical services and systems librarians) would have little or no direct contact with library users. It was surprising, then, to find that the relationship with library users came out as the single most satisfactory item on the Canadian study as well.

Other items in the top five most satisfactory elements were benefits, oppor- 


\begin{tabular}{|c|c|}
\hline \multicolumn{2}{|c|}{$\begin{array}{c}\text { TABLE } 2 \\
\text { Aspects of Practice Ranked Most } \\
\text { to Least Satisfactory, } \\
\text { Based on Responses of Total Sample }\end{array}$} \\
\hline Satisfaction variable & Mean \\
\hline Relationship with library users & 3.86 \\
\hline Benefits & 3.82 \\
\hline Opportunities to use own judgment & 3.81 \\
\hline Relationship with nonprofessional staff & 3.80 \\
\hline Assigned duties & 3.75 \\
\hline Relationship with professional colleagues & 3.75 \\
\hline Opportunities for independent action & 3.64 \\
\hline Salary & 3.57 \\
\hline Working conditions & 3.51 \\
\hline Opportunities for variety & 3.45 \\
\hline Librarians' status at your university & 3.41 \\
\hline Opportunities for challenge & 3.38 \\
\hline $\begin{array}{l}\text { Opportunities for professional } \\
\text { participation }\end{array}$ & 3.26 \\
\hline Relationship with library administration & 3.19 \\
\hline Promotion and tenure process & 3.05 \\
\hline Management style & 2.95 \\
\hline $\begin{array}{l}\text { Opportunities to participate in } \\
\text { library management }\end{array}$ & 2.95 \\
\hline Recognition of accomplishments & 2.91 \\
\hline Workload & 2.89 \\
\hline Promotion opportunities & 2.88 \\
\hline Performance review process & 2.85 \\
\hline Relationship with univ. administration & 2.83 \\
\hline Support for publication and research & 2.74 \\
\hline Participation in univ. decision-making & 2.50 \\
\hline
\end{tabular}

istration, support for publication and research, and participation in university decision-making. The items on workload and recognition of accomplishments were sixth and seventh lowest, but, again, if support for publication/ research and performance review are dropped (because they were not in Horenstein's survey), then they are among the lowest five. Accordingly, three of the items ranked lowest in the authors' study (recognition of accomplishments, promotion opportunities, and relationship with university administration) were also the lowest in Horenstein's study.

With respect to workload in particular, the averaging of satisfaction scores ranked it near the bottom, with a mean of 2.89 (2.96 in Horenstein's study). In other words, levels of satisfaction with workload were below satisfactory on the scale. This point was brought home by forty-five respondents $(28 \%$ of those commenting), all of whom remarked that their workloads were a very distressing aspect of their positions. The most frequent concern was that as resources (both human and fiscal) continued to shrink, the

tunties to use own judgment, relationship with nonprofessional staff, and assigned duties. Relationship with colleagues came sixth, but if the item concerning relationship with nonprofessional staff is removed from the analysis (because it was not in Horenstein's survey), then relationship with colleagues is in the top five. Thus, four items in the top five in the Canadian study (relationship with users, judgment, duties, and relationship with colleagues) were also in the top five in the American study.

Items ranked lowest were promotion opportunities, performance review process, relationship with university admin- pressures to do more in their workday steadily increased. Thus, the current climate of cutbacks in government funding to higher education in Canada appears to be having a very tangible impact on individual academic librarians.

The strong similarity of the findings between the two studies regarding the elements of satisfaction caused the authors to rethink the meaning of table 2 and the comparable table in Horenstein's paper. They were intrigued by the notion that a very large sample of North American academic librarians, in two different countries, had said that despite all the other attractions or benefits of working 
in an academic environment, the single most satisfactory element of their work was their relationship to their clientele. In thinking about the implications of this finding, the authors noted that the items in table 2 split roughly into two parts intrinsic measures (such as relationship with users, opportunities for challenge, independence, judgment) were ranked in the top half, whereas extrinsic measures (such as management's style, promotion opportunities, relationship with administration) fell in the bottom half, with a few exceptions. This distribution is even more startling in Horenstein's data, where the midpoint item on working conditions marks a turning point; items ranked above it are intrinsic measures and those below it are extrinsic. ${ }^{19}$ This distribution suggests that academic librarians are most satisfied with the traditonal elements of librarianship as a profession (such as service, working with users, independence of work, challenge) and less satisfied with the peculiarities of working in an academic environment where occupational status, promotion and tenure, publishing, and political involvement are a concern, all of which are components of the faculty- or academicstatus model.

\section{Academic Status and Job Satisfaction}

To examine the relationship between academic status and job satisfaction in greater detail, analysis of variance was used to determine the satisfaction of two groups of librarians - those with academic status $(n=463)$ and those without $(n=269)-$ on the satisfaction items (shown in table 2), and the composite satisfaction score. Significant differences found through the analysis are presented in table 3.

Generally, the Canadian study did not find as many significant differences as did the American research. Overall satisfaction (from the final question) and composite satisfaction levels did not differ significantly between academic-status librarians and other librarians. Nevertheless, Canadian librarians who have faculty/academic status do seem to be

\begin{tabular}{|c|c|c|c|c|c|}
\hline \multicolumn{6}{|c|}{$\begin{array}{c}\text { TABLE } 3 \\
\text { Significant Differences in Satisfaction, by Group } \\
\text { (Academic vs. Nonacademic Status) }\end{array}$} \\
\hline Variable & $\begin{array}{l}\text { Overall } \\
\text { Mean }\end{array}$ & Academic & $\begin{array}{l}\text { Non- } \\
\text { academic }\end{array}$ & Signif. & PRE* \\
\hline $\begin{array}{l}\text { Librarians' status at your } \\
\text { university }(n=726)\end{array}$ & 3.41 & 3.60 & 3.08 & .000 & .045 \\
\hline Opportunities for challenge $(n=727)$ & 3.38 & 3.48 & 3.21 & .003 & .012 \\
\hline $\begin{array}{l}\text { Opportunities for professional } \\
\text { participation and development }(n=727)\end{array}$ & 3.26 & 3.38 & 3.06 & .000 & .022 \\
\hline$\dagger$ Promotion and tenure process $(\mathrm{n}=697)$ & 3.05 & 3.20 & 2.76 & .000 & .038 \\
\hline $\begin{array}{l}\text { Promotion and advancement } \\
\text { opportunities }(n=716)\end{array}$ & 2.88 & 3.01 & 2.65 & .000 & .022 \\
\hline $\begin{array}{l}\text { Relationship with university } \\
\text { admin. }(n=702)\end{array}$ & 2.83 & 2.91 & 2.67 & .004 & .011 \\
\hline Support for research $(n=679)$ & 2.74 & 2.85 & 2.53 & .001 & .017 \\
\hline $\begin{array}{l}\text { Opportunities to participate in univ. } \\
\text { manage. and decision-making }(n=714)\end{array}$ & 2.50 & 2.64 & 2.25 & .000 & .029 \\
\hline
\end{tabular}


more satisfied with their status in the university, and with opportunities available to them for challenge, promotion, professional participation, and participation in the university. They are also more satisfied with the promotion and tenure process and with support for doing research, but this is not surprising given that most faculty collective agreements clearly outline how these two processes should work, thus removing a potential cause of dissatisfaction.

There were a number of differences found significant in Horenstein's study that were not evident in the Canadian data. For instance, having academic status in Canada did not appear to affect satisfaction with salary and benefits nor with the relationship with the library administration or participation in library management. It is likely that these results are directly related to the fact that the academic-status model common in Canada emphasizes evaluative criteria based on professional responsibilities rather than teaching, research, and university service. Salaries and benefits, therefore, would not vary as much as they would in the United States, where some academic librarians have full faculty status and rank (and thus different priorities and salary), some have a modified form of faculty status, and others have neither.

In both studies, academic-status librarians were not significantly more satisfied with their assigned duties, workloads, opportunities to use their own judgment or act independently, and relationships with users and colleagues.

\section{Administration and Job Satisfaction}

As noted earlier, it was observed informally during data entry that librarians who had indicated that their primary service area or department was administration appeared to have high levels of satisfaction. The questions that arose from this observation were: (1) Would administrators have higher levels of satisfaction than librarians who did not have administrative responsibilities (i.e., those working primarily as reference librarians, cataloguers, systems librarians, etc.)? and (2) In the Canadian context, would administration prove to be a more significant determinant of satisfaction than academic status?

Table 4 presents the results of analysis of variance performed on the administrative $(n=279)$ and nonadministrative $(n=459)$ groupings. In general, administrators appear to be significantly more satisfied than nonadministrators with those elements relating to control over their work, including opportunities to use their own judgment, act independently, and experience challenge in their work. They are also more satisfied with the opportunities to participate in both library and university decision-making and, not surprisingly, are more satisfied with their relationship with library and university administration, and the management style in the library. Perhaps because of their greater participation in library decision-making, they are also more satisfied with promotion, tenure, and performance review processes. In addition, administrators are more satisfied with the working conditions and responsibilities. Finally, they also have higher overall levels of satisfaction on both the single-question and the composite satisfaction scores. It appears, therefore, that having administrative responsibilities tends to increase overall job satisfaction, a finding also strongly supported in the work of Lynch and Verdin. ${ }^{20}$ Furthermore, highly significant differences between administrators and nonadministrators were found on eighteen items (table 4), suggesting that administration may be a better predictor of job satisfaction for Canadian academic librarians than academic status, which produced highly significant differences on only eight items (table 3).

Once again, no significant differences between administrators and nonadministrators were found regarding salary, 


\begin{tabular}{|c|c|c|c|c|c|}
\hline \multicolumn{6}{|c|}{$\begin{array}{c}\text { TABLE } 4 \\
\text { Significant Difference in Satisfaction, by Group } \\
\text { (Administration vs. Nonadministration) }\end{array}$} \\
\hline Variable & $\begin{array}{c}\text { Overall } \\
\text { Mean }\end{array}$ & Admin. & $\begin{array}{l}\text { Non- } \\
\text { admin. }\end{array}$ & Signif. & PRE \\
\hline Benefits $(n=736)$ & 3.82 & 3.94 & 3.74 & .006 & .010 \\
\hline Opportunities to use own judgment $(n=724)$ & 3.81 & 4.10 & 3.62 & .000 & .051 \\
\hline Assigned duties $(n=730)$ & 3.75 & 3.96 & 3.62 & .000 & .026 \\
\hline $\begin{array}{l}\text { Opportunties for independence } \\
\text { of action }(\mathrm{n}=735)\end{array}$ & 3.64 & 3.93 & 3.46 & .000 & .043 \\
\hline Working conditions $(n=734)$ & 3.51 & 3.84 & 3.30 & .000 & .059 \\
\hline Opportunities for job enrichment $(n=730)$ & 3.45 & 3.75 & 3.26 & .000 & .044 \\
\hline Opportunities for challenge $(n=733)$ & 3.38 & 3.70 & 3.17 & .000 & .049 \\
\hline $\begin{array}{l}\text { Opportunities for professional } \\
\text { participation }(n=733)\end{array}$ & 3.26 & 3.49 & 3.11 & .000 & .030 \\
\hline Relations with library admin. $(n=723)$ & 3.19 & 3.63 & 2.92 & .000 & .078 \\
\hline Promotion and tenure process $(n=703)$ & 3.05 & 3.22 & 2.94 & .001 & .014 \\
\hline Management style $(n=729)$ & 2.95 & 3.37 & 2.69 & .000 & .073 \\
\hline $\begin{array}{l}\text { Opportunities to participate in library } \\
\text { decision-making }(\mathrm{n}=727)\end{array}$ & 2.95 & 3.66 & 2.51 & .000 & .185 \\
\hline Recognition of accomplishments $(n=727)$ & 2.91 & 3.13 & 2.77 & .000 & .025 \\
\hline Opportunities for promotion $(n=722)$ & 2.88 & 3.18 & 2.69 & .000 & .039 \\
\hline Performance review process $(\mathrm{n}=711)$ & 2.85 & 2.99 & 2.75 & .004 & .011 \\
\hline Relations with university admin. $(n=707)$ & 2.83 & 3.11 & 2.64 & .000 & .048 \\
\hline Support for research $(n=684)$ & 2.74 & 2.92 & 2.63 & .001 & .015 \\
\hline $\begin{array}{l}\text { Opportunities to participate in univ. } \\
\text { manage. and decision-making }(\mathrm{n}=720)\end{array}$ & 2.50 & 2.86 & 2.26 & .000 & .072 \\
\hline
\end{tabular}

workload, and relationships with users, colleagues, and staff.

\section{Participation and Academic Status}

Horenstein posed the question: "To what extent do academic librarians participate in library planning and decision-making, university academic affairs, and professional activities beyond their institution?" ${ }^{21}$ Would different groups of librarians have different levels of participation?

Participation measures are found throughout the questionnaire. A number of questions looked at actual participation through teaching, meetings attended, membership in library organizations, and conference attendance. Participation of librarians in library management and decision-making was also assessed in several other questions having to do with internal structures of the li-

brary. Also, librarians' perceptions of their participation were measured on a four-point scale in questions that explored the extent to which librarians felt involved, consulted, and informed regarding decision-making in the library, the control they had over their professional activities, their participation in university affairs and professional activities outside their library, and their involvement in evaluating colleagues.

Horenstein found relatively few differences in actual participation among the three groups of librarians she considered. ${ }^{22}$ This was also true in the Canadian study: no highly significant differences were found between academic-status librarians and other librarians in terms of teaching, attending library and university meetings, or conference attendance. Academic status librarians did tend to 
have more memberships in library associations $(\mathrm{p}<.01, \mathrm{PRE}=.050)$.

However, perceived participation proved to be a different matter. Horenstein noted that faculty librarians felt "more involved in library planning and decision making, more consulted, more informed by the administration about matters affecting the library, and more involved in the university than other librarians." ${ }^{23}$ Librarians with full faculty status and rank felt most involved, whereas those with neither felt least involved.

This study only partially confirmed Horenstein's findings about the relationship between perceived participation and faculty status. As table 5 shows, academic-status librarians in Canada do not perceive themselves as more in control over their daily work and more involved in decision-making nor do they feel more consulted and informed about matters affecting the library. They do, however, perceive themselves to be more involved in evaluating their colleagues (perhaps because of their participation in the tenure process), participating more in professional activities beyond their institutions (not found significant by Horenstein), and participating more in institutional academic affairs. Thus, the findings in common between the two studies regarding perceived participation were: librarians with faculty/academic status do not perceive themselves as having more control over their daily work than other librarians, but they do perceive themselves to be participating more in university affairs. A third finding, that academic-status librarians are significantly more involved in evaluating their colleagues, was not explored by Horenstein.

\section{Participation and Administration}

As was the case with the various aspects of job satisfaction, administration proved to be a slightly stronger predictor of differences in participation than academic status.

With respect to actual participation, there were significant differences between administrative and nonadministrative librarians regarding participation in library and university meetings (administrators attend more), and teaching (administrators teach less). They were also more likely to be aware of decisions made by the library planning group or council than other librarians. However, there were no significant differences in professional memberships or conference attendance.

There were significant differences between library administrators and nonadministrators in all of the perceived participation items (table 5). Administrators

\begin{tabular}{|c|c|c|c|c|}
\hline \multicolumn{5}{|c|}{$\begin{array}{c}\text { TABLE } 5 \\
\text { Significant Differences in Perceived Participation, by Group } \\
\end{array}$} \\
\hline Variable* & $\begin{array}{l}\text { Academic } \\
\text { Status }\end{array}$ & $\begin{array}{l}\text { Nonacademic } \\
\text { vs. } \quad \text { Status }\end{array}$ & $\begin{array}{l}\text { Non- } \\
\text { admin. vs. }\end{array}$ & Admin. \\
\hline $\begin{array}{l}\text { Involved in management } \\
\text { and decision-making }\end{array}$ & \multicolumn{2}{|c|}{ Not significant } & 3.37 & 2.25 \\
\hline Feels consulted & \multicolumn{2}{|c|}{ Not significant } & 3.48 & 2.80 \\
\hline Feels informed & \multicolumn{2}{|c|}{ Not significant } & 3.45 & 2.77 \\
\hline Control over own activities & \multicolumn{2}{|c|}{ Not significant } & 3.59 & 3.31 \\
\hline University participation & 2.18 & 1.67 & 2.34 & 1.77 \\
\hline Professional participation & 2.56 & 2.29 & 2.61 & 2.36 \\
\hline Evaluation of others & 2.41 & 1.76 & 2.80 & 1.80 \\
\hline
\end{tabular}


felt more in control over their work, more involved in decision-making, and more consulted and informed about library matters. They also perceived themselves as being more involved in evaluating colleagues, participating more in professional activities beyond their institutions, and participating more in the university.

\section{Participation and Satisfaction}

\begin{tabular}{|c|c|}
\hline \multicolumn{2}{|l|}{$\begin{array}{c}\text { TABLE } 6 \\
\text { Correlations of Participation with } \\
\text { Composite Satisfaction } \\
\end{array}$} \\
\hline Variables & $\begin{array}{l}\text { Composite } \\
\text { Satisfaction* }\end{array}$ \\
\hline $\begin{array}{l}\text { Actual participation (in teaching, meetings, } \\
\text { professional organizations, conferences) }\end{array}$ & .1525 \\
\hline $\begin{array}{l}\text { Feels involved, informed, consulted about } \\
\text { library decisions; in control of own activitie }\end{array}$ & ies .7059 \\
\hline $\begin{array}{l}\text { Perceived participation in university affairs } \\
\text { and extra-institutional professional activiti }\end{array}$ & ies .3182 \\
\hline Involved in evaluating colleagues & .3764 \\
\hline
\end{tabular}

Do librarians who participate more on the various dimensions discussed above also have greater levels of job satisfaction? To answer this question, Horenstein ran correlations between the participation items and all the satisfaction items. In addition, composite scores were created for actual and perceived participation and correlated with satisfaction. She found that librarians who scored high in actual and perceived participation also scored high in satisfaction.

Using the same methodology, this study also generally confirms these findings (table 6). There is a positive relationship between actual participation (in

\section{Administrators felt more in control over their work, more involved in decision-making, and more consulted and informed about library matters.}

teaching, meetings, professional associations, conferences) and satisfaction, but the correlation (.1525) is rather weak. However, in terms of perceived participation, there is a very strong relationship (.7059) between the composite of items related to decision-making (feeling involved in library decision-making, consulted and informed about library matters, and in control of daily work) and overall job satisfaction. Also, there is a significant relationship between the composite of items relating to external involvement (participation in university affairs and professional activities beyond the insitution) and overall satisfaction. Involvement in the evaluation of colleagues is also related to overall satisfaction. Both studies, therefore, have confirmed that greater levels of actual and perceived participation do increase job satisfaction.

\section{Demographic Variables and Satisfaction}

What other factors, beyond participation and status, might affect job satisfaction? To answer this, the demographic characteristics of the respondents were examined with regard to satisfaction. Horenstein found that higher levels of benefits (sabbaticals, tenure, research grants, etc.) were associated with higher levels of overall satisfaction, as were higher salaries and more experience as a librarian. On the other hand, gender and the department of respondents were not found to be strongly associated with overall satisfaction. ${ }^{25}$

The authors took a slightly different approach to demographic factors, and again used analysis of variance to determine whether there were significant differences in satisfaction based on the characteristics of the respondents or their li- 


\begin{tabular}{|lccc|}
\hline \multicolumn{4}{|c|}{ TABLE 7} \\
\multicolumn{4}{|c}{$\begin{array}{c}\text { Significant Differences in Satisfaction } \\
\text { by Demographic Variables }\end{array}$} \\
\hline \hline Variable & F Ratio & PRE & Signif. \\
\hline $\begin{array}{l}\text { Decision-making } \\
\quad \text { model in library }\end{array}$ & 80.79 & .299 & .000 \\
$\begin{array}{l}\text { Management style in library* } \\
\text { Department }\end{array}$ & 72.31 & .221 & .000 \\
$\begin{array}{l}\text { Regular meetings of } \\
\quad \text { professional librarians }\end{array}$ & 24.52 & .077 & .000 \\
$\begin{array}{l}\text { Salary } \\
\text { Experience }\end{array}$ & 44.23 & .071 & .000 \\
Eligibility for tenure/ & 9.66 & .063 & .000 \\
$\quad$ continuing appt. & 4.84 & .024 & .002 \\
Eligibility for seats on & 11.63 & .019 & .001 \\
$\quad$ university governance & 10.28 & .017 & .001 \\
Eligibility for sabattical & 8.83 & .015 & .003 \\
\hline * Not included in Horenstein's study. & & & \\
\hline
\end{tabular}

gree as the previous variables. This compares to Horenstein's finding that salary, eligibility for tenure, and sabattical were related to higher overall satisfaction.

Department did appear to affect satisfaction, but this could be due to the presence of a large number of administrative librarians in the sample. When administrative librarians were removed from the analysis, there were no significant differences in satisfaction by department, which is comparable to Horenstein's finding using correlation.

Variables that did not produce significant differences in overall satisfaction were gen-

braries. Although their study confirmed some of Horenstein's findings, the authors also found other interesting differences in satisfaction not previously revealed.

In terms of the characteristics of libraries, table 7 shows that both the decisionmaking model in the library (i.e., how much librarians are able to participate in decision-making) and the management style of the library are perhaps the most significant factors in this group of variables affecting librarians' overall satisfaction. In particular, librarians who were the most involved in library decisionmaking were also more satisfied. Those who indicated that the management style in their library was autocratic were significantly less satisfed than those who indicated a team or collegial approach. Also related to these variables, a library that had regular meetings of the professional staff resulted in higher levels of satisfaction.

In terms of the characteristics of librarians, salary, experience, and elibility for tenure, sabattical, and governance seats also produced significant differences in satisfaction, although not to the same deder, education, librarian status, publication requirements, and the presence or absence of a library council. Again, these findings are comparable to Horenstein's that gender, education, and publication requirements are not associated with higher overall satisfaction.

\section{Stepwise Regression}

Using a stepwise regression of all the variables most closely correlated with overall satisfaction, Horenstein found that the best predictors of overall satisfaction were the perceived participation variables (feeling involved, informed, consulted, and in control of daily activities), followed by salary and academic rank. ${ }^{26}$

Using the same approach, the Canadian study generally confirms these findings. The perceived participation variables regarding feeling involved in library decision-making, consulted and informed about library matters, in control over one's work, and involved in evaluating colleagues proved to be the best predictors of overall satisfaction. Following these variables, the degree of librarians' participation in library management and deci- 
sion-making also proved to be a strong predictor, although it was not found to be so by Horenstein. Salary, found to be important by Horenstein, did not prove to be a strong predictor of overall satisfaction, even though correlation did show a mild relationship between the two.

\section{Conclusion}

This study and Horenstein's have found that librarians report above satisfactory levels of job satisfaction, a finding also noted by other authors. ${ }^{27}$ Also, when responses of the entire sample are considered, both studies found that the intrinsic aspects of librarianship (such as relationship with users, creativity, or challenge) were the elements of their work that librarians indicated were the most satisfying. What are the implications of this? It would seem that what academic librarians find satisfying or attractive about their work are the traditional elements of librarianship itself - a strong emphasis on service, with ample opportunities for challenge, independence, creativity, using one's judgment, and participation in professional activities. What they appear to find less satisfying are the

\section{Administrative librarians are significantly more satisfied with their ability to participate in library decision-making and planning, their relationship with the library administration, and management style in the library.}

requirements of practicing librarianship in an academic environment, where they must be overly concerned with occupational status, promotion, evaluation, and library and university governance, all of which are emphasized when librarians attain faculty status. These findings seem to support authors such as Rachel Applegate, who have argued that the pursuit of faculty status for academic librarians has been based on a set of incorrent assumptions about who librarians are and what they should be doing within insitutions of higher education. ${ }^{28}$

However, the situation may not be so clear-cut because other factors also appear to affect the satisfaction equation. Horenstein was able to demonstrate that librarians with both faculty status and rank were clearly the most satisfied with their work. Although the Canadian study does not have data that are entirely comparable, its findings do show that Canadian university librarians with academic status are more satisfied with certain dimensions of their work, including their status within the institution and their opportunities to participate outside the library, in either professional activities or the university. In addition, related to the latter, they are more satisfied with their relationship with the university administration and university processes such as promotion and tenure. However, they are not more satisfied with other important features of their work, such as workload or duties; salary; relationship with colleagues, staff, and users; and opportunties to use their own judgment, to exercise independent action, or for job enrichment.

A further complication in the satisfaction equation is that, in the Canadian context, having administrative responsibilities appears to have an even stronger impact on overall satisfaction than does academic status. Administrative librarians are significantly more satisfied with their ability to participate in library decision-making and planning, their relationship with the library administration, and management style in the library. They are also more satisfied with the opportunities available to them regarding promotion, job enrichment, challenge, using their own judgment, and independence of action. Also, they are more satisfied in terms of assigned duties, working conditions, and benefits, though not salary. 
What do faculty/academic-status librarians and administrative librarians have in common that would account for increased satisfaction levels in those groups? The answer appears to have something to do with actual or perceived participation. However, in both Horenstein's and in this research, academic status did not result in significant differences in actual participation (as measured through teaching, attending library and university meetings, attending conferences, etc.). Furthermore, this study found that although administrative librarians did have significiant differences in their actual participation, this was not true for all the variables. Actual participation, then, does not seem to account adequately for differences in job satisfaction.

Horenstein has stated: "Perception of participation appears to be the crucial factor in job satisfaction," and the authors of this study would concur. ${ }^{29}$ Both academic-status and administrative librarians felt significantly more involved, consulted, and informed with respect to library matters and more in control over their work than other librarians. They also perceived themselves to be more involved in university decision-making and planning, and in evaluating their colleagues. These results are also very consistent with the authors' analysis of the characteristics of respondents and their libraries, which showed that librarians in institutions with a collegial or team management style, and a model of decision-making that allowed greater input from librarians, had higher overall satisfaction. Demographic variables such as education, gender, department, and to a certain extent salary were relatively unimportant as predictors of overall satisfaction when compared to the perceived participation variables.

In light of the findings regarding participation, which have now been confirmed in two large-scale studies, the question remains as to what is the best mechanism for increasing actual and perceived participation, and thus providing greater job satisfaction for academic librarians. The authors' data suggest that there may not be one best route to achieving this goal.

One traditional way for academic librarians to widen their responsibilities and progress in their careers has been to apply for successively more senior, more managerial positions. Administrative duties often also bring with them opportunities to participate at a higher level, through committee work and collaborative projects. For those who succeed in attaining a managerial position, job satisfaction does seem to be enhanced significantly. Administrative librarians felt much more involved in library decisionmaking and planning, and were noticeably more satisfied with many of the instrinsic and extrinsic aspects of their work.

Unfortunately, this route is no longer an option for many academic librarians who choose to remain at one institution for a large part of their careers. First, there have always been far fewer managerial positions than working academic librarians. Second, there is a trend toward reducing the number of managerial positions in academic libraries in favor of more streamlined organizational structures. And, third, not every librarian aspires to a managerial position. Instead, many prefer to remain at the front lines of service as reference librarians, cataloguers, collections specialists, and systems librarians. This is entirely consistent with the authors' findings that it is the nature of librarianship itself that is deeply satisfying to the majority of academic librarians. Horenstein concluded:

Faculty status and rank may offer a solution to the routine nature of the profession, by adding greater involvement within the university as a way to enrich the jobs of academic librarians. ${ }^{30}$ 
However, her data also clearly demonstrate that unless the faculty-status model is rigorously applied to the highest level, greater satisfaction may not result. The Canadian study echoes this: in general, Canadian university librarians with academic status are not more involved when actual participation measures are considered and do not perceive themselves to be more in control of their work, more involved in library decisionmaking, more consulted, and more informed about library matters. ${ }^{31}$ These findings suggest that faculty/academic status must be taken seriously by the administration of both the library and the university if it is to be a means of providing greater involvement and opportunities and of rekindling enthusiasm. The written comments of respondents in the authors' study also confirm that having the trappings of faculty status, without the real benefits, is an undesirable state of affairs. An excellent example of this is the issue of eligibility for sabattical or research leave. Personal comments from numerous librarians indicated that although they did have such eligibility, they were actively discouraged from taking research leaves because of institutional constraints such as inadequate staffing. Such institutional barriers are unlikely to result in greater job satisfaction for the librarians at those sites.

Because they manage and develop one of the most important symbols of higher education, academic librarians should be at the center of campus life. But, like the faculty, who also spend most of their professional lives at one institution, to achieve this they must feel rewarded and satisfied with their work and contributions to the institution. This study has shown that academic librarians, in general, have levels of job satisfaction that are slightly higher than merely satisfactory. However, those with either some form of faculty status or administrative responsibilities perceive themselves to be more actively involved in the decisionmaking processes of the library and/or the university, and as a result, have significantly higher levels of satisfaction on many dimensions. In addition, librarians in academic libraries where the managerial style is toward a team or collegial approach, and where there is a high level of input into library decision-making by librarians, are more satisfied with their jobs, findings that are also strongly supported in the work of Bengston and Shields. ${ }^{32}$ These findings suggest, then, that the faculty/academic-status model is not necessarily the best, nor the only way to provide greater participation opportunities for academic librarians over the course of their working lives.

The authors would like to acknowledge funding from the Social Sciences and $\mathrm{Hu}$ manities Research Council of Canada (Grant K023A3). They would also like to thank their research assistant, Kim Kofmel, for her able assistance.

\section{Notes}

1. Bonnie Horenstein, "Job Satisfaction of Academic Librarians: An Examination of the Relationships between Satisfaction, Faculty Status, and Participation," College \& Research Libraries 54 (May 1993): 255-69.

2. See, for instance, George D'Elia, "The Determinants of Job Satisfaction among Beginning Librarians," Library Quarterly 49 (July 1979): 282-302; Dale Susan Bengston and Dorothy Shields, "A Test of Marchant's Predictive Formulas Involving Job Satisfaction," Journal of Academic Librarianship 11 (May 1985): 88-92; Beverly Lynch and JoAnn Verdin, "Job Satisfaction in Libraries: A Replication," Library Quarterly 57 (April 1987):190-202; and Mohammad Mirfakhrai, "Correlates of Job Satisfaction among Academic Librarians in the United States," Journal of Library Administration 14 (1991): 117-31. 
3. Two examples are Marjorie Benedict, "Librarians' Satisfaction with Faculty Status," College E Research Libraries 52 (Nov. 1991): 538-48; and Horenstein, "Job Satisfaction of Academic Librarians."

4. Steven Chwe, "A Comparative Study of Job Satisfaction: Catalogers and Reference Librarians in University Libraries," Journal of Academic Librarianship 4 (July 1978): 139-43.

5. Susanne Wahba, "Job Satisfaction of Librarians: A Comparison between Men and Women," College \& Research Libraries 36 (Jan. 1975): 45-51.

6. Ilene Rockman, "Job Satisfaction among Faculty and Librarians: A Study of Gender, Automony, and Decision Making Opportunities," Journal of Library Administration 5 (fall 1984): 43-56.

7. D'Elia, "The Determinants of Job Satisfaction," 299.

8. Patricia A. Kreitz and Annegret Ogden, "Job Responsibilities and Job Satisfaction at the University of California Libraries," College \& Research Libraries 51 (July 1990): 297-312.

9. Horenstein, "Job Satisfaction of Academic Librarians."

10. Benedict, "Librarians' Satisfaction with Faculty Status."

11. Tina Hovekamp, "Unionization and Job Satisfaction among Professional Library Employees in Academic Research Institutions," College \& Research Libraries 56 (July 1995): 341-50.

12. Horenstein, "Job Satisfaction of Academic Librarians."

13. Gloria J. Leckie and Jim Brett, "Academic Status for Canadian University Librarians: An Examination of Key Terms and Conditions," Canadian Journal of Information and Library Science 20 (Apr. 1995): 1-28.

14. Academic status usually does not confer on librarians the identical ranks or titles used by the faculty, although there is no consistency in this across universities. Also, performance criteria may or may not include the same criteria as for faculty (i.e., teaching, research, service). For example, academic status for librarians frequently entails a substitution of "professional duties" for teaching, and a loosening of the criteria for what is considered to be acceptable in terms of research.

15. Horenstein excluded managerial librarians, preferring instead to concentrate on frontline librarians. The authors included managerial librarians, thus bringing the number of primary service areas or departments to ten, including acquisitions, administration, cataloging, circulation, collections, document delivery/ILL, reference, serials, systems, and other.

16. Horenstein, "Job Satisfaction of Academic Librarians," 259.

17. Ibid., 258.

18. Ibid., 258.

19. Ibid., 261.

20. Lynch and Verdin, "Job Satisfaction in Libraries," 197.

21. Horenstein, "Job Satisfaction of Academic Librarians," 261.

22. Ibid., 262.

23. Ibid., 262.

24. Ibid., 263.

25. Ibid., 263.

26. Ibid., 264.

27. Kreitz and Ogden, "Job Responsibilities," 307.

28. Rachel Applegate, "Deconstructing Faculty Status: Research and Assumptions," Journal of Academic Librarianship 19 (July 1993): 158-64.

29. Horenstein, "Job Satisfaction of Academic Librarians," 264.

30. Ibid., 265.

31. However, librarians with academic/faculty status are more satisfied with other dimensions of their work, as the earlier section on Academic Status and Job Satisfaction has discussed.

32. Bengston and Shields, "A Test of Marchant's Predictive Formulas," 91. 